\title{
Pielonefritis enfisematosa
}

\author{
Duque Fernández de Vega S, González Ortega FJ, Ruiz de Arévalo A, Narvona S *, Tinaut J**. \\ Servicio de Radiodiagnóstico. *Servicio de Cuidados Críticos. **Servicio de Urología. \\ Hospital Clínico San Cecilio de Granada.
}

Actas Urol Esp. 2008;32(4):473

$\mathrm{V}_{\mathrm{p}}^{\mathrm{a}}$ arón de 80 años, diabético e hipertenso, con arteriopatía periférica y amputación supracondílea de miembro inferior izquierdo que acude al Servicio de Urgencias de nuestro hospital tras haber completado tratamiento en la última semana con ciprofloxacino ante la sospecha de infección urinaria. A su ingreso en Urgencias refiere dolor abdominal difuso continuo de 3 días de evolución sin cortejo vegetativo acompañante que no cedía a tratamiento analgésico convencional (primer escalón de la OMS). En la exploración destaca deterioro del estado general, hipotensión, fiebre, signos de hipoperfusión, sin detectarse masas ni peritonismo a la exploración abdominal.

En las pruebas complementarias solicitadas se detecta leucocitosis, neutrofilia y acidosis metabólica con descompensación glucémica. En la orina se observa presencia de leucocituria y bacterias

En la radiografía simple de abdomen no se visualizaron hallazgos significativos.

Al no encontrarse justificación de la clínica, y ante la sospecha de patología arterial aguda se solicita TC abdominal que descarta afectación vascular pero en cambio pone de manifiesto una disminución focal de la densidad del parénquima renal derecho con pérdida de la diferenciación corticomedular y pobre definición de la superficie cortical en la zona afecta. Destaca además la presencia de pequeñas burbujas aéreas intraparenquimatosas en la porción más superior y periférica del área referida, que junto con los hallazgos anteriores y la clínica séptica nos llevaron al diagnóstico definitivo de pielonefritis enfisematosa.

Tras consultar con el Servicio de Urología de guardia se decide actitud conservadora en espera de evolución, por lo que el paciente se trasladó a la Unidad de Cuidados Intensivos tratándose con poliantibioterapia de amplio espectro y drogas vasoactivas. Una semana más tarde el paciente es dado de alta ante la buena respuesta al tratamiento tanto desde el punto de vista clínico como radiológico.

La pielonefritis enfisematosa es una infección fulminante del riñón y tejidos perirrenales que cursa con gas producido, por orden de frecuencia, por E. coli, Proteus, y raramente por Clostridium.

Los factores predisponentes son: estados de inmunosupresión, especialmente la diabetes (es donde ocurre el 90\% de los casos), y la obstrucción renoureteral.

La mortalidad es muy alta, aunque con la nefrectomía desciende a un $30 \%$.

El diagnóstico se realiza con la demostración de gas en el sistema ureteral o en el intersticio del parénquima, incluso en el espacio perirrenal.

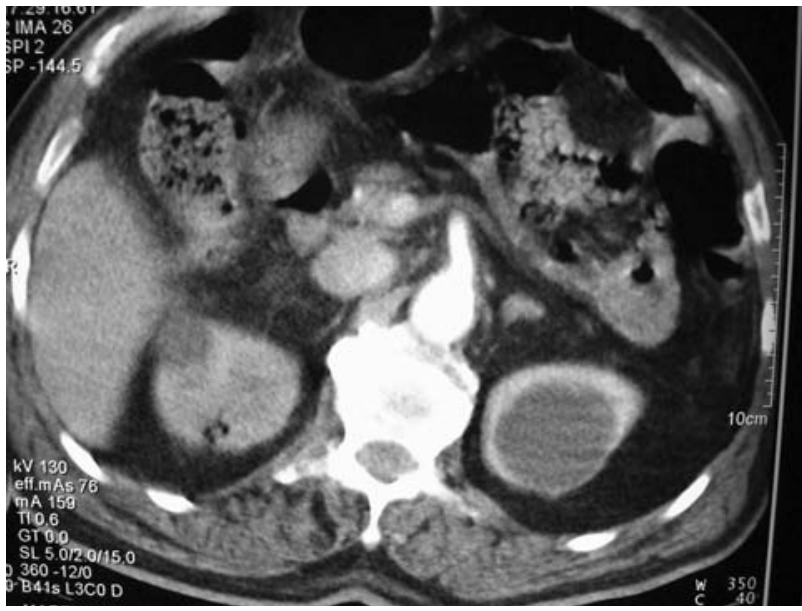

\section{FIGURA 1}

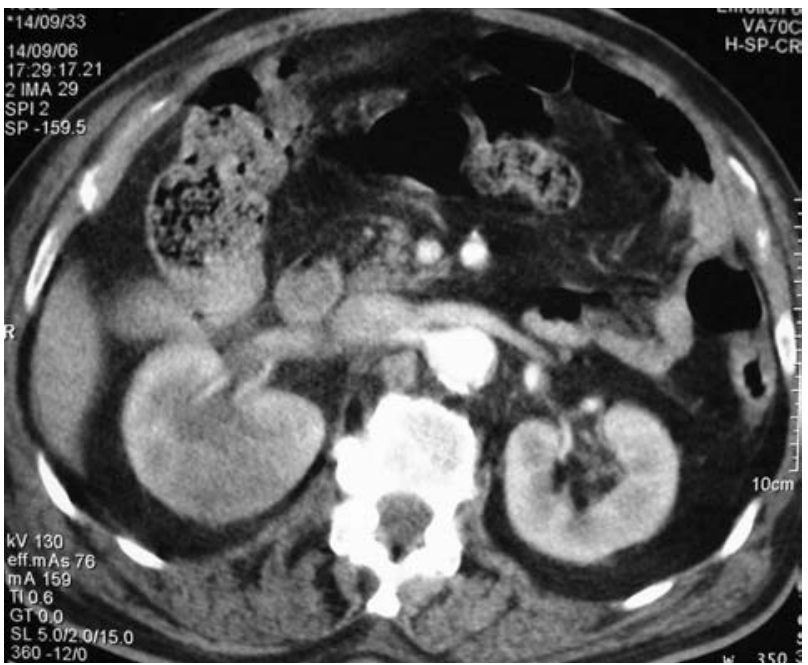

FIGURA 2

Presentamos este caso porque suele ser rara la buena evolución de este proceso sin recurrir a la nefrectomía, sobre todo en paciente ancianos pluripatológicos como nuestro caso. Algo que creemos se debió al diagnóstico precoz radiológico.

Correspondencia autor: Dr. S. Duque Fernández de Vega Servicio de Radiodiagnóstico.

Hospital Clínico Universitario San Cecilio. Granada.

Avda. del Doctor Olóriz, 16 - 18012 Granada. Tel.: 958023231

E-mail autor: sandraduquefv@gmail.com

Información artículo: Imágenes en Urología

Trabajo recibido: diciembre 2006

Trabajo aceptado: enero 2007 